\title{
Changes in Neurotrophic Factor Expression and Receptor Activation Following Exposure of Hippocampal Neuron/Astrocyte Cocultures to Kainic Acid
}

\author{
John S. Rudge, Elizabeth M. Pasnikowski, Patricia Holst, and Ronald M. Lindsay \\ Regeneron Pharmaceuticals, Inc., Tarrytown, New York 10591
}

Neurotrophic factor expression in the adult mammalian CNS is largely neuronal. However, upon traumatic injury reactlve astrocytes express a number of neurotrophic factors including ciliary neurotrophic factor (CNTF), fibroblast growth factor (FGF), and NGF. In this study, we examined whether the upregulation of neurotrophic factors in reactive astrocytes and cultured astrocytes is a consequence of separation from their neuronal counterparts, and whether neurotrophic factor levels can be regulated by placing astrocytes into coculture with neurons. We show that reIntroduction of rat hippocampal neurons to rat hippocampal astrocytes in vitro leads to a time dependent downregulation in astrocytes of the neurotrophic factors CNTF, NGF, and neurotrophin 3 (NT-3). In contrast, brain-derived neurotrophic factor (BDNF) mRNA, which is only expressed in neurons in these cultures is slightly increased. Once neurotrophic factor levels in cocultures had reached a steady state in the neuron/glia cocultures, we initiated a traumatic event with the excitotoxin kainic acid. BDNF protein was rapidly upregulated within $24 \mathrm{hr}$ after lesion, whereas CNTF protein upregulation was delayed reaching maximal levels by $3 \mathrm{~d}$. Despite the endogenous upregulation of both of these trophic factors, no activation of their respective receptors, as measured by tyrosine phosphorylation, was detectable following kainate administration. However, following addition of exogenous CNTF at any time point up to $24 \mathrm{hr}$ after kainate administration, the $\beta$ components of the CNTF receptor (LIFR $\beta$ and gp130) could be phosphorylated. Furthermore, although activation of neuronal LIFRß and gp130 by exogenous CNTF declined during the period of neuronal death, these receptors reappeared on astrocytes and could be activated by CNTF. In contrast, phosphorylation of TrkB by exogenous BDNF was undetectable by $24 \mathrm{hr}$ and could not be reactivated after this point. These data suggest that the intimate association of astrocytes and neurons in the CNS serves to suppress astrocyte-derived neurotrophic factor expression and that neuronal loss leads to a derepression of neurotrophic fac-

\footnotetext{
Received May 8, 1995; revised June 19, 1995; accepted June 22, 1995.

We gratefully acknowledge Neil Stahl for his advice in all matters concerning signal transduction, Tony Gard for his critical review of the manuscript, and Lone Frank, Peter DiStefano, Rory Curtis, Roseann Ventimiglia, and Pam O'Neil for rewarding scientific discussion. We also thank Claudia Murphy and Eric Hubel for their excellent photographic skills and Dr. Len Schleifer for providing a stimulating environment in which to work.

Correspondence should be addressed to Dr. John S. Rudge, Regeneron Pharmaceuticals Inc., 777 Old Saw Mill River Road, Tarrytown, NY 10591.
}

Copyright (O) 1995 Society for Neuroscience $0270-6474 / 95 / 156856-12 \$ 05.00 / 0$ tor synthesis in astrocytes. However, the upregulation of endogenous BDNF and CNTF observed after excitotoxic lesion in this culture model are insufficient to activate signal transduction and protect against neuronal loss.

[Key words: brain-derived neurotrophic factor, ciliary neurotrophic factor, signal transduction, epilepsy, ischemia, excitotoxicity, receptor regulation]

Astrocytes have been implicated in a wide variety of supportive functions for their partner neurons in the CNS, such as neuronal guidance during development and nutritional and metabolic support throughout life (Rakic, 1971; Varon and Somjen, 1979; Shao and McCarthy, 1994). Astrocytes have also been suggested to provide neurotrophic factors essential for neuronal maintenance and survival (Lindsay, 1979; Banker, 1980; Manthorpe et al., 1986; Rudge, 1993). This hypothesis has been fostered by numerous studies where cultured "type 1" astrocytes release trophic activities that promote survival and differentiation of a number of different neuronal types in vitro. Confirming these observations, astrocytes have been found to express mRNA and protein for a number of defined neurotrophic factors such as members of the neurotrophin family, pleiotropic factors such as ciliary neurotrophic factor (CNTF) and basic fibroblast growth factor (bFGF) (for reviews, see Manthorpe et al., 1986; Rudge, 1993). Due to their capacity to express neurotrophic factors in vitro, it was therefore puzzling when in situ hybridization studies revealed that expression of several neurotrophic factors, such as NGF, was almost completely neuronal (Ayer-LeLievre et al., 1988; Whittemore et al., 1988; Bandtlow et al., 1990; Ernfors et al., 1990; Gall et al., 1991). Although there are some exceptions, such as expression of NGF in astrocytes of the early developing optic nerve (Lll et al., 1991), and expression of CNTF in the mature optic nerve (Stockli et al., 1991) and glia limitans of the adult rat brain (Ip et al., 1993b), neurotrophic factor production is not a property of most astrocytes within normal adult brain parenchyma. This situation changes dramatically following brain injury.

Traumatic injury to the adult mammalian CNS leads to a well documented reactive gliosis (Berry et al., 1983) in which reactive astrocytes are capable of expressing NGF (Lu et al., 1991; Altar et al., 1992; Lindholm et al., 1992; Yoshida and Gage, 1992), CNTF (Ip et al., 1993; Asada et al., 1995) bFGF (Frautschy et al., 1991), and, as yet, undefined biological activities, as assessed by actions on cultured neurons (Nieto-Sampedro et al., 1983). Suggestive of increased endogenous neurotrophic activity in the brain after injury is the finding that lesioning of the CNS prior to transplantation of embryonic striatum into the entorhinal 
cortex resulted in dramatically improved survival of the transplants at the peak period of glial reaction and neurotrophic factor production (Nieto-Sampedro et al., 1983). Thus, we became interested in the mechanisms that control neurotrophic factor expression in astrocytes in vivo and the functional consequences of this regulation.

In this study, we have used a defined model of cultured "type 1 " astrocytes, which can be obtained at greater than $95 \%$ purity, and characterized their expression of neurotrophic factors (Rudge et al., 1992). Type 1 astrocytes have been shown to express NGF (Norrgren et al., 1980; Furukawa et al., 1986; Yamakuni et al., 1987), brain-derived neurotrophic factor (BDNF; Zafra et al., 1990), neurotrophin-3 (NT-3; Rudge et al., 1992), ncurotrophin 4/5 (NT4/5; Condorelli et al., 1994), CNTF (Stockli et al., 1989), and bFGF (Ferrara et al., 1988). The levels of these neurotrophic factors can also be regulated independently of GFAP as has been shown for NGF (Furukawa et al., 1987; Friedman et al., 1990; Carman-Krzan et al., 1991), BDNF (Zafra et al., 1992), NT-3 (Condorelli et al., 1994), and CNTF (Carroll et al., 1994; Rudge et al., 1994a). However, the high level of expression of these factors in astrocytes in vitro is more reminiscent of a reactive astrocyte population than a resting astrocyte population in vivo. In order to develop a model where the levels of neurotrophic factor expression in astrocytes are more reflective of their levels in situ, we have cocultured embryonic hippocampal neurons with hippocampal astrocytes and examined the regulation of neurotrophic factors over time in coculture. We find that there is a time dependent downregulation of neurotrophic factor expression when neurons are cocultured with astrocytes, which can be rapidly reversed if the neurons are injured by an excitotoxic lesion. However, the upregulation of endogenous BDNF and CNTF proteins after trauma does not result in phosphorylation of their respective receptors, suggesting that there are further levels of regulation controlling functional stimulation of neurons after trauma. Indeed, exogenously administered CNTF can stimulate its receptor up to $24 \mathrm{hr}$ after lesion resulting in a functional response that is biphasic as receptor phosphorylation declines as neurons die but then is reinduced on the astrocytes that remain. In contrast, phosphorylation of TrkB by exogenous BDNF is lost as neurons die but then is never regained.

\section{Materials and Methods}

Hippocampal neuron/astrocyte coculture. Astrocytes were cultured from postnatal day 1 rat hippocampi as described previously (Rudge et al., 1992, 1994b). After $28 \mathrm{~d}$ in vitro and one passage, the confluent monolayer of astrocytes was seeded with E18 rat hippocampal neurons prepared as described previously (Ip et al., 1991; Rudge et al., 1994b). The neurons were seeded at a density of $4 \times 10^{6}$ cells $/ 100 \mathrm{~mm}$ dish or $0.8 \times 10^{6}$ cells $/ 35 \mathrm{~mm}$ dish in DME containing $10 \%$ fetal calf serum. The medium was changed 4 hir later, to a serum free formulation of DME containing N2 supplements; $50 \%$ of this medium was changed twice a week for the next 2 weeks.

Northern analysis of neurotrophic factor levels in neuron/astrocyte coculture. Total astrocyte RNA was prepared from hippocampal astrocyte/neuron cocultures by extraction in $4 \mathrm{M}$ guanidinium thiocyanate, followed by phenol/chloroform extraction. Total RNA was extracted from adult rat brain tissue using $0.3 \mathrm{M} \mathrm{LiCl} / 6 \mathrm{M}$ urea followed by phenol chloroform extraction. Ten micrograms of RNA were electrophoresed on a formaldehyde agarose gel and transferred to a nylon membrane (MSI, Westboro, MA), and hybridized to ${ }^{32} \mathrm{P}$ probes labeled by random oligo priming (Stratagene, La Jolla, CA). Equal loading of RNA samples was confirmed by ethidium-stained gels.

The probes used to examine gene expression and regulation included cDNA fragments to CNTF (600 bp coding region), GFAP (2.7 kb, a kind gift of Dr. Ronald Liem), BDNF (800 bp), NT3 (800 bp), and NGF
(1.3 kb). Bands were quantified on a Fuji Bioimager using PDQ software and visualized by autoradiography on Bionax film (Kodak, Rochester, NY).

Western blotting. Using a 1\% NP40 lysis buffer containing protease inhibitors (lp et al., 1992), lysates of astrocyte/neuron cocultures were prepared with at $1,7,14$, and $21 \mathrm{~d}$ after neurons were seeded onto a confluent monolayer of astrocytes. Lysates were then boiled in sample buffer and electrophoresed on $12 \%$ (CNTF and GFAP) or $7.5 \%(200$ $\mathrm{kDa}$ neurofilament) polyacrylamide gels. Gels were blotted to Immobilon and then probed with the following antibodies: CNTF (RG0036; Friedman et al., 1992), GFAP (AB1982, Chemicon, Temecula, CA), and $200 \mathrm{kDa}$ neurofilament (N52; Boehringer Mannheim, Indianapolis, IN) Primary antibodics werc visualized using secondary antibodics linked to HRP followed by the enhanced chemiluminescent reaction (Amersham, Arlington Heights, IL). Bands for CNTF (24 kDa), GFAP (41 $\mathrm{kDa})$, and neurofilament ( $200 \mathrm{kDa}$ ) were quantified using a PerkinElmer scanning densitometer. Levels of CNTF were further quantified by running control lanes with recombinant rat CNTF to obtain a standard curve. The levels of TrkB present in cocultures after the addition of kainate were determined by extracting cultures at time 0 (with and without treatment with $50 \mathrm{ng} / \mathrm{ml}$ BDNF) and at $2 \mathrm{hr}, 6 \mathrm{hr}, 18 \mathrm{hr}, 24 \mathrm{hr}$, and $48 \mathrm{hr}$ after treatment with kainate. Glycoproteins containing an $\mathrm{N}$-acetyl glucosamine residue, of which TrkB is one, were precipitated with wheat germ agglutinin (Knusel et al., 1994), washed and bound material run on Western blots. The blots were probed with a specific antibody to TrkB (Signal Transduction labs 1/2000) and visualized using the ECL reaction.

Cytotoxicity assay. To examine the time course over which kainic acid was cytotoxic to neurons in the rat hippocampal neuron/astrocyte coculture, we added acridine orange (final concentration, $0.25 \mathrm{ng} / \mathrm{ml}$ ) and propidium iodide (final concentration, $2.5 \mathrm{ng} / \mathrm{ml}$ ) to the cultures. Acridine orange was taken up by viable cells and fluoresced green under fluorescein optics on a Zeiss Axioplan inverted stage microscope, and propidium iodide was taken up by dead cells and fluoresced orange under rhodamine optics. These two reagents were added for $30 \mathrm{~min}$, either prior to the addition of $50 \mu \mathrm{M}$ kainic acid or to sister cultures at $3,6,8,16,20,24,30$, and $48 \mathrm{hr}$ after addition of kainate. The percentage of dead cells was determined by counting the number of propidium iodide stained cells at these time points and expressing the number obtained as a percentage of the maximal number of dead cells obtained at $48 \mathrm{hr}$.

Two site BDNF ELISA. Astrocytes or neuron/astrocyte cocultures were treated with $50 \mu \mathrm{M}$ kainic acid and then after $0,2,6,18,24$, and $48 \mathrm{hr}$, conditioned medium was removed and stored at $-80^{\circ} \mathrm{C}$ prior to assay. At the same time points, the cells were extracted in lysis buffer $(50 \mathrm{~mm}$ Tris $\mathrm{pH} 7.5,0.3 \mathrm{M} \mathrm{NaCl}, 0.1 \%$ Triton X-100, $1 \%$ BSA, $1 \mathrm{~mm}$ benzamidine, $0.1 \mathrm{~mm}$ benzethonium chloride, $1 \mu \mathrm{g} / \mathrm{ml}$ aprotinin, $1 \mu \mathrm{g} /$ $\mathrm{ml}$ leupeptin, and $1 \mathrm{~mm}$ PMSF). The BDNF two site ELISA was carried out as defined previously (Acheson et al., 1995). A monoclonai antibody to recombinant human BDNF (RP 43-01) was bound to Immulon 4 microtiter plates as a capture antibody. After washing, test samples were added in a 1:1 dilution of lysis buffer and PBS + 1\% BSA. A biotinylated polyclonal antibody specific for BDNF (C. A. Altar and S. Radka, unpublished observations) was then added as a reporter. Following incubation, bound antibody was visualized using a horseradish peroxidase-avidin D conjugate followed by TMB substrate. The resulting color change was read at $450 \mathrm{~nm}$ on an Applied Biosystems 96 well plate reader and expressed in $\mathrm{ng} / \mathrm{ml}$ of $\mathrm{BDNF}$ relative to a standard curve of known rHuBDNF concentrations. The range of the standard curve was $2 \mathrm{ng} / \mathrm{ml}$ to $0.008 \mathrm{ng} / \mathrm{ml}$ and the sensitivity of the assay was set at a concentration of the BDNF standard which was $2 \times$ the OD of the blank.

Immunocytochemistry. Cucultures of hippocampal astrocyles and neurons were fixed in $4 \%$ paraformaldehyde in PBS at the following time points: $1 \mathrm{~d}$ after the neurons were seeded onto the astrocyte monolayer, $14 \mathrm{~d}$ after coculture, and $3 \mathrm{~d}$ after addition of $50 \mu \mathrm{M}$ kainate to cocultures ( $17 \mathrm{~d}$ of coculture). Cells were then placed in blocking buffer (3\% horse or goat serum, $0.1 \%$ Tween $20,150 \mathrm{~mm} \mathrm{NaCl}, 10 \mathrm{~mm}$ Tris $\mathrm{HCl} \mathrm{pH} 7.5$ ) and then incubated overnight with a rabbit polyclonal antibody directed against GFAP (Chemicon, AB1980), a rabbit polyclonal antibody directed against rat CNTF (RG0036) or a mouse monoclonal against neurofilament protein (Boehringer Mannheim RT97). The cells were then rinsed four times, $10 \mathrm{~min}$ each, in KPBS containing $0.02 \%$ Triton $\mathrm{X}-100$ and $0.25 \%$ bovine serum albumin, and incubated for $1 \mathrm{hr}$ in biotinylated goat anti-rabbit or anti-mouse secondary anti- 

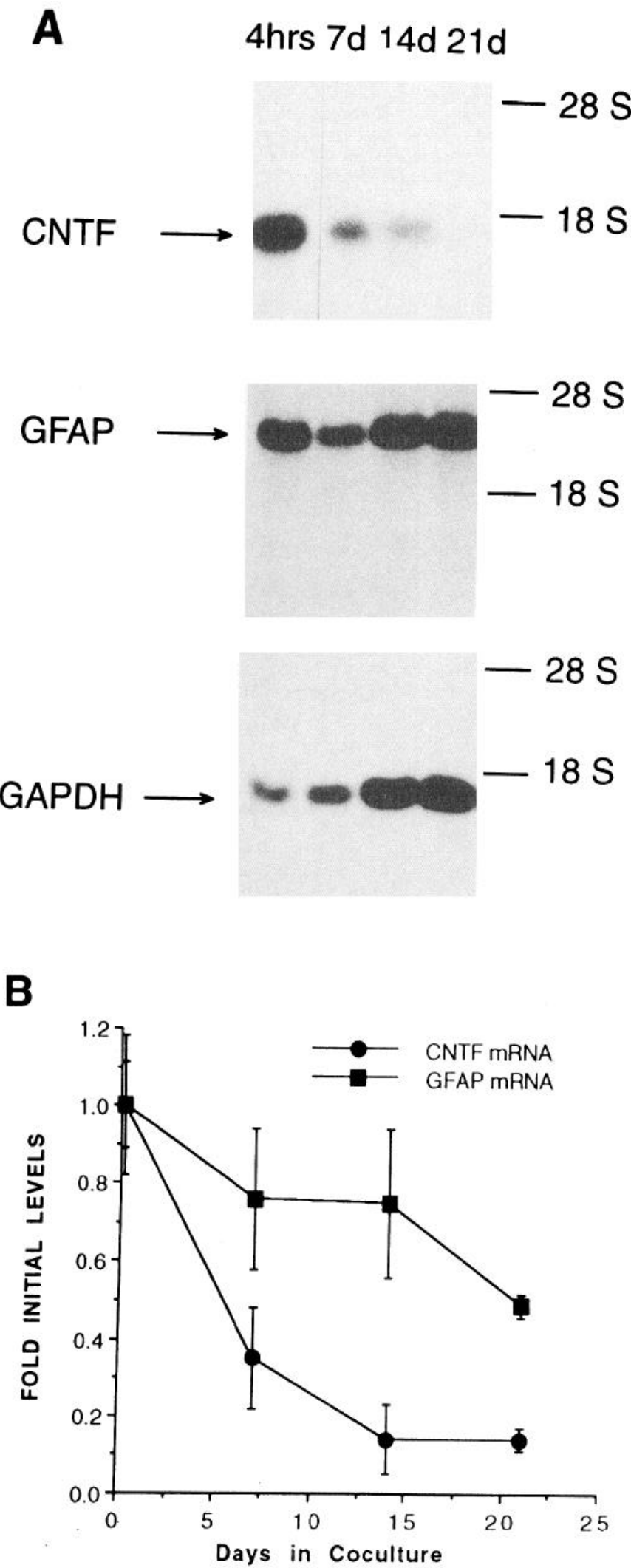

Figure 1. Differential regulation of CNTF mRNA and GFAP mRNA expression over time in hippocampal neuron/astrocyte coculture. A, Northern analysis. E18 rat hippocampal neurons were seeded onto a confluent monolayer of rat hippocampal astrocytes $(28 \mathrm{~d}$ in vitro) and RNA extracted from the coculture after $4 \mathrm{hr}, 7 \mathrm{~d}, 14 \mathrm{~d}$, and $21 \mathrm{~d}$. Northern blots were run and probed for CNTF mRNA, GFAP mRNA, and GAPDH mRNA. B, Quantitation. Northern blots $(n=3-5)$ were body at a dilution of $1: 1,500$, followed by a $60 \mathrm{~min}$ rinse in KPBS After a $1 \mathrm{hr}$ incubation in avidin-biotin-peroxidase complex (Vector Elite Kit, Vector, Burlingame, CA), the cells were rinsed in acetateimidazole and the HRP visualized with diaminobenzidine (DAB) intensified with nickel sulfate.

Protein tyrosine phosphorylation. As a measure of the phosphorylation state of TrkB, $14 \mathrm{~d}$ cocultures were extracted in lysis buffer (Ip et al., 1992) either prior to addition of kainate or at $2 \mathrm{hr}, 6 \mathrm{hr}, 18 \mathrm{hr}$, $24 \mathrm{hr}$, and $48 \mathrm{hr}$ after kainate exposure. At the same time points, a parallel set of cultures were treated with BDNF $(50 \mathrm{ng} / \mathrm{ml})$ for $5 \mathrm{~min}$ prior to extraction. Samples were immunoprecipitated with a pan-Trk antibody (RG145) and the resultant Western blots probed with an antibody to phosphotyrosine (UBI 4G10). The level of sensitivity of the assay was determined by adding BDNF to $14 \mathrm{~d}$ cocultures at $50,5,0.5$, and $0.05 \mathrm{ng} / \mathrm{ml}$ for $5 \mathrm{~min}$, extracting the cells in lysis buffer, immunoprecipitating with RG145 and probing the blot with the anti-phosphotyrosine antibody. Concentrations of BDNF less than $5 \mathrm{ng} / \mathrm{ml}$ did not result in detectable phosphorylation of TrkB above background.

As a measure of CNTF receptor activation, and thus a measure of the functional status of the receptor, cocultures were examined for their endogenous level of phosphorylation prior to the addition of kainic acid and $2 \mathrm{hr}, 6 \mathrm{hr}, 1 \mathrm{~d}, 2 \mathrm{~d}, 3 \mathrm{~d}$, and $7 \mathrm{~d}$ afterwards. Phosphorylation of the CNTF receptor $\beta$ components (LIFR $\beta$ and gp130) was measured by preparing protein lysates in $1 \%$ NP40 lysis buffer (supplemented with proteinase and phosphatase inhibitors) as previously described (Ip et al., 1992) followed by immunoprecipitation with a specific LIF receptor $\beta$ antibody (RG134, Regeneron Pharmaceuticals) and protein G conjugated to sepharose (Pharmacia, Piscataway, NJ). Immunoprecipitates were then electrophoresed on $7.5 \%$ polyacrylamide gels, immunoblotted with anti-phosphotyrosine antibodies as previously described (Ip et al., 1992) and specific proteins detected by enhanced chemiluminescence (ECL, Amersham).

To determine the capacity of the cells to respond to CNTF over the above time course, cultures were treated with $50 \mathrm{ng} / \mathrm{ml}$ recombinant rat CNTF for $15 \mathrm{~min}$ at $0,2 \mathrm{hr}, 6 \mathrm{hr}, 1 \mathrm{~d}, 2 \mathrm{~d}, 3 \mathrm{~d}$, and $7 \mathrm{~d}$ following kainate administration. The samples were then processed in the same way as described above for assessment of receptor phosphorylation.

\section{Results}

The presence of neurons decreases the levels of CNTF $m R N A$ and $C N T F$ protein in cultured astrocytes

$C N T F$ mRNA. Confluent astrocytes in vitro are known to possess high levels of CNTF mRNA and GFAP mRNA (Stockli et al., 1989; Rudge et al., 1992), whereas neither CNTF mRNA nor GFAP mRNA are present in cultured hippocampal neurons as measured by Northern analysis (Rudge et al., 1992). However, when astrocytes were cultured with embryonic hippocampal neurons, CNTF message (1.2 kb) was downregulated over $21 \mathrm{~d}$ in coculture reaching a level that was only $20 \%$ of that observed after a $4 \mathrm{hr}$ incubation with neurons (Fig. 1A,B). The level of CNTF mRNA at $21 \mathrm{~d}$ of coculture was similar to that found in a sample of adult rat brain run in an adjacent lane on the same Northern blot (data not shown). GFAP mRNA was also downregulated by $21 \mathrm{~d}$ of coculture, but more gradually, falling by $21 \mathrm{~d}$ to $50 \%$ of that observed $1 \mathrm{~d}$ after neurons were seeded onto the astrocytes. Although there was an evident change in their morphology during this time period, the number of astrocytes in culture did not change (data not shown). This is in agreement with the findings of Hatten et al. who showed that coculture of astrocytes with neurons inhibited astrocyte proliferation (Hatten, 1985).

CNTF protein. To determine whether the changes in RNA for

$\leftarrow$

quantified by exposing the blots to the image plate of a Fuji Bioimager and the bands quantified using PDQ software with the values obtained at $4 \mathrm{hr}$ set as an initial level of 1.0 for each probe. Differential loading was corrected for by comparing values obtained for CNTF mRNA and GFAP mRNA to the value obtained for GAPDH mRNA. 
A

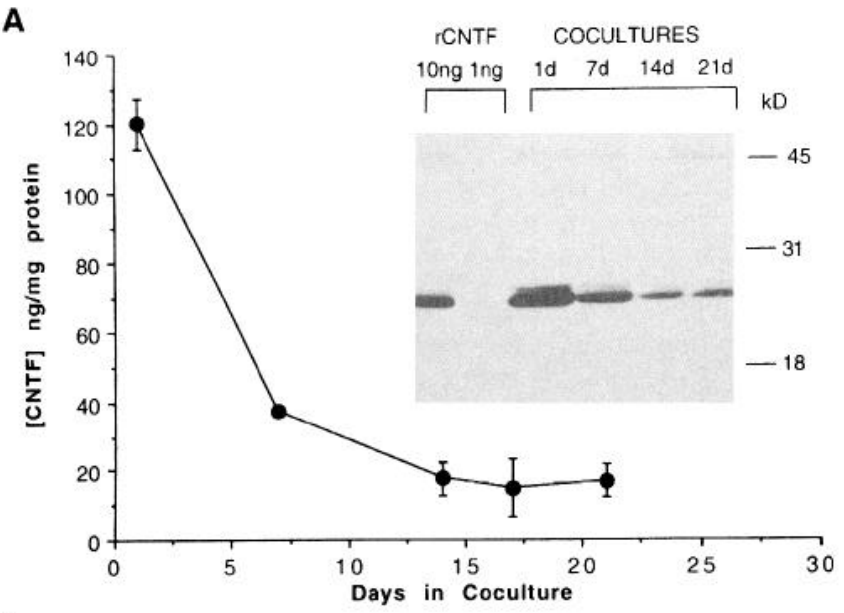

B

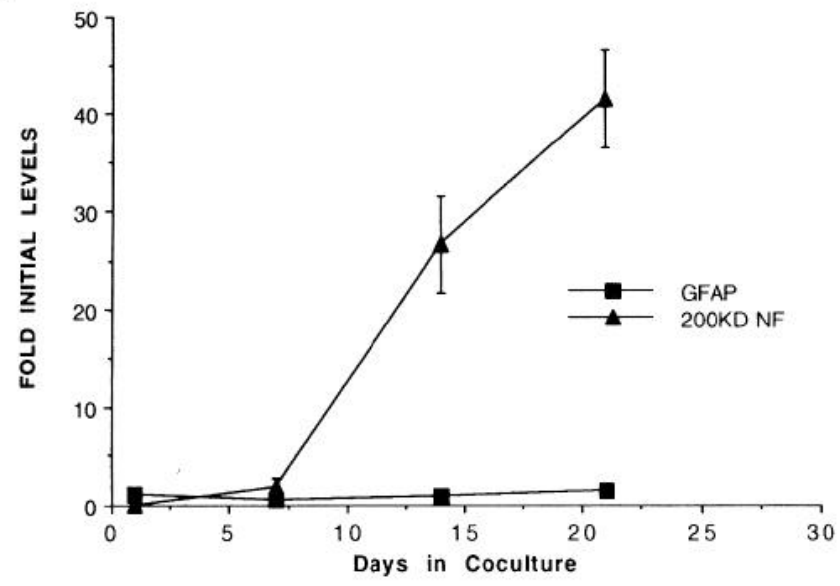

Figure 2. Regulation of CNTF, GFAP, and neurofilament protein over time in hippocampal neuron/astrocyte coculture. $A$, Western blot analysis of CNTF. E18 rat hippocampal neurons were seeded onto a confluent monolayer of rat hippocampal astrocytes $(28 \mathrm{~d}$ in vitro) and cocultures extracted in lysis buffer at $1,7,14,17$, and $21 \mathrm{~d}$ later. Western blots were run and probed with a rabbit polyclonal antibody to CNTF (RG0036). The inset shows the Western blot in which recombinant rat CNTF $10 \mathrm{ng}$ and $1 \mathrm{ng}$ were run next to $1 \mathrm{~d}, 7 \mathrm{~d}, 14 \mathrm{~d}$, and $21 \mathrm{~d}$ cocultures. $(n=4)$. $B$, Western blot analysis of GFAP and $200 \mathrm{kDa}$ neurofilament. The same protocol as outlined in $A$ was applied, except that Western blots were probed for GFAP (41 kDa) or neurofilament protein $(200 \mathrm{kDa})$ and quantified using a Perkin-Elmer densitometer $(n$ $=4)$.

CNTF and GFAP in coculture were also reflected in a change in protein levels, we used Western blotting with specific antibodies for each of these proteins. In addition, we used an antibody to the $200 \mathrm{kDa}$ subunit of neurofilament protein as a quantitative measure of neuronal survival and growth. We found that CNTF protein decreased from $120 \mathrm{ng} / \mathrm{mg}$ total protein to $20 \mathrm{ng} /$ mg total protein over $14 \mathrm{~d}$ in coculture (Fig. $2 A$ ). In contrast, neurofilament protein increased by 40 -fold over $21 \mathrm{~d}$ in coculture reflecting very extensive neuritic outgrowth (Fig. $2 B$ ). The decrease in CNTF protein over time in coculture could possibly be due to a dilution effect produced by an increase in the amount of neuronal protein contributing to total protein. However, when CNTF levels were recalculated as ng/well rather than $\mathrm{ng} / \mathrm{mg}$ protein, a similar decrease was observed (data not shown). Over time in coculture, GFAP protein levels remained fairly constant, despite a $50 \%$ decrease in GFAP mRNA, suggesting that GFAP protein is slowly turned over.
Table 1. Regulation of neurotrophic factor mRNA after $14 \mathrm{~d}$ in hippocampal neuron/astrocyte coculture

\begin{tabular}{ll}
$\begin{array}{l}\text { Neurotrophic factor } \\
\text { (transcript size) }\end{array}$ & $\begin{array}{l}\text { Fold control levels } \\
(4 \mathrm{hr} \text { after seeding }=1.0)\end{array}$ \\
\hline NGF $(1.3 \mathrm{~kb})$ & $0.39 \pm 0.01$ \\
BDNF $(4.0 \& 1.6 \mathrm{~kb})$ & $1.47 \pm 0.24$ \\
NT3 $(1.4 \mathrm{~kb})$ & $0.53 \pm 0.11$ \\
CNTF $(1.2 \mathrm{~kb})$ & $0.2 \pm 0.01$
\end{tabular}

E18 rat hippocampal neurons were seeded onto a confluent monolayer of rat hippocampal astrocytes in serum containing medium and $4 \mathrm{hr}$ later the medium was changed to a serum free formulation (see Materials and Methods). At this time one set of cultures was processed for Northern analysis, and the value obtained from quantitation of the indicated transcripts for each neurotrophic factor was set at 1.0. The cocultures were allowed to mature for $14 \mathrm{~d}$ and another set of cultures was processed for Northern analysis. The value obtained from quantitation of this set of cultures was compared to the original value to give a measure of the change in RNA levels between $4 \mathrm{hr}$ and $14 \mathrm{~d}$ in coculture. Values represent the mean $\pm \mathrm{SD}$ of four separate estimations.

\section{$N G F, N T 3$, and CNTF mRNA decrease over time in coculture whereas BDNF mRNA increases}

To determine whether CNTF is regulated differently from other neurotrophic factors in this system, we also examined the regulation of NGF, BDNF and NT-3 mRNA after $14 \mathrm{~d}$ of coculture. Table 1 shows that NGF mRNA and NT-3 mRNA were decreased relative to their levels at the start of the coculture, whereas BDNF mRNA levels were increased to about 1.5 -fold the level at the start of the coculture. As we have shown previously, cultured hippocampal astrocytes express NGF mRNA, NT-3 mRNA, and CNTF mRNA but not BDNF mRNA whereas cultured hippocampal neurons possess BDNF mRNA and NT-3 mRNA but not NGF mRNA or CNTF mRNA (Rudge et al., 1992). The differential regulation observed in this study may be explained by a decline in astrocyte-derived neurotrophic factors and an increase in neuron-derived neurotrophic factors. This has already been suggested for NGF in a cortical neuron/astrocyte coculture system (Vige et al., 1992).

Table 2. Regulation of CNTF mRNA levels in neuron/astrocyte coculture by exogenous agents

Additive Fold control levels

Control

$1.0 \pm 0.16$

Clonidine $(10 \mu \mathrm{M})$

$\gamma$ interferon $(30 \mathrm{ng} / \mathrm{ml})$

IL $1 \beta(10 \mathrm{ng} / \mathrm{ml})$

TNF $\alpha(100 \mathrm{ng} / \mathrm{ml})$

TGFß1 $(10 \mathrm{ng} / \mathrm{ml})$

Kainate $(50 \mu \mathrm{M})$

$1.29 \pm 0.05$

$0.99 \pm 0.21$

$0.82 \pm 0.08$

$0.84 \pm 0.12$

$0.95 \pm 0.14$

$2.81 \pm 0.56$

E18 rat hippocampal neurons were seeded onto a confluent monolayer of rat hippocampal astrocytes in serum-containing medium and $4 \mathrm{hr}$ later the medium was changed to a serum free formulation (see Materials and Methods). After $14 \mathrm{~d}$ in coculture, the reagents listed above were added at the concentrations indicated and the cocultures incubated for a further $24 \mathrm{hr}$. At this time, the cocultures were processed for RNA, run on Northern blots, and probed for CNTF mRNA. The $1.2 \mathrm{~kb}$ transcript of CNTF mRNA in control cultures that had received only serum-free medium for $24 \mathrm{hr}$ was quantified using a Fuji Bioimager and PDQ software and set at 1.0. Treated cultures were quantified in the same way and compared to the value for controls. These values represent the mean $\pm \mathrm{SD}$ of three separate estimations. IL1 $\beta$, interleukin $1 \beta ;$ TNF $\alpha$, tumor necrosis factor $\alpha$; TGF $\beta 1$, Transforming growth factor $\beta 1$. 

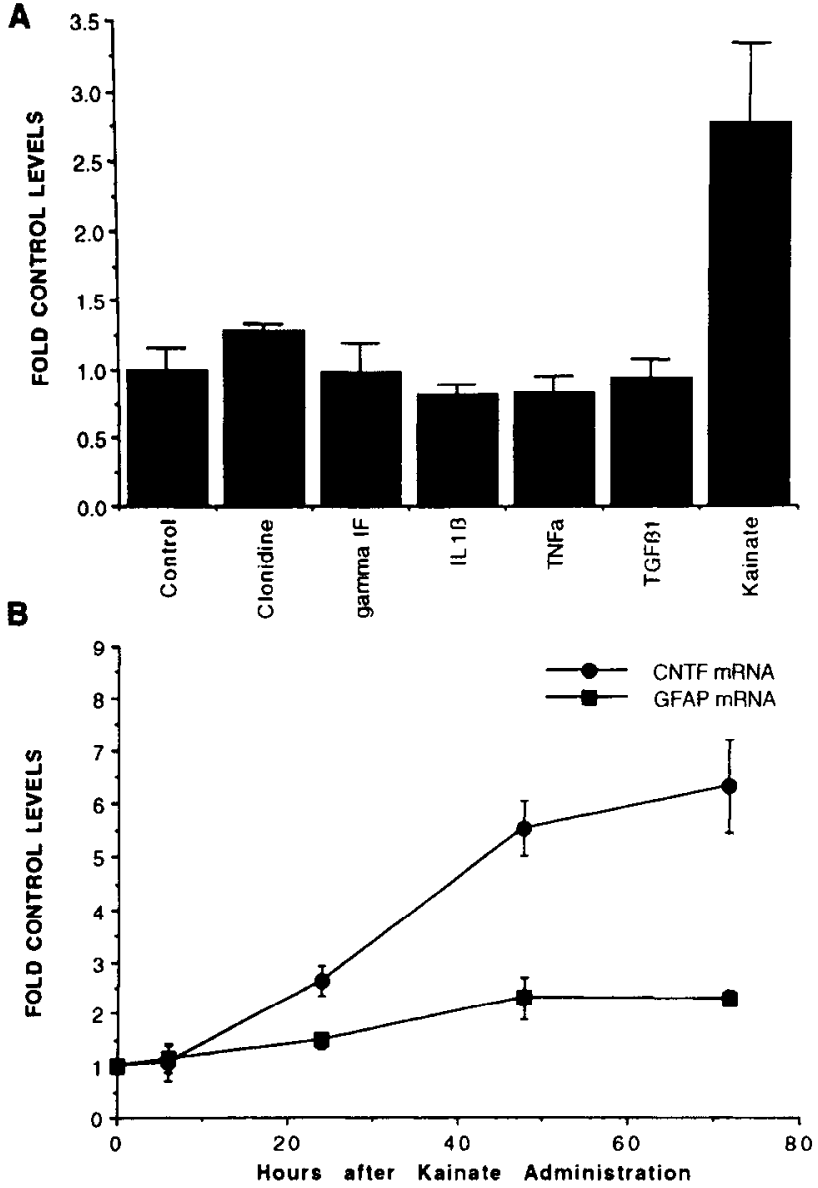

\section{C}

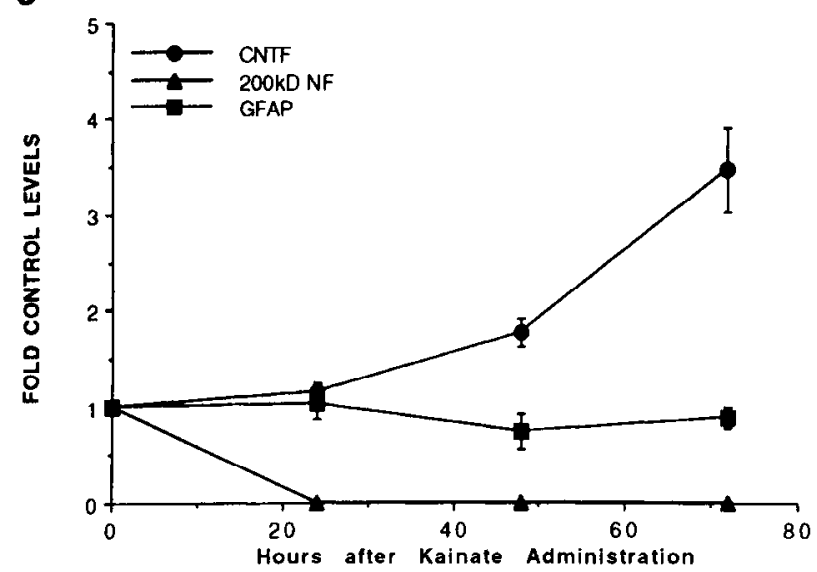

Figure 3. Regulation of CNTF, GFAP, and neurofilament protein in neuron/astrocyte coculture. $A$, Northern blot analysis of CNTF mRNA after addition of exogenous agents. E18 rat hippocampal neurons were seeded onto a confluent monolayer of rat hippocampal astrocytes in serum containing medium and $4 \mathrm{hr}$ later the medium was changed to a serum-free formulation (see Materials and Methods). After $14 \mathrm{~d}$ in coculture, the reagents shown were added and the cocultures incubated for a further $24 \mathrm{hr}$. At this time, the cocultures were processed for RNA, run on Northern blots and probed for CNTF mRNA. The $1.2 \mathrm{~kb}$ transcript of CNTF mRNA in control cultures which had received only serum free medium for $24 \mathrm{hr}$ was quantified using a Fuji Bioimager and PDQ software and set at 1.0. Treated cultures were quantified in the same way and compared to the value for controls. These values represent the mean $\pm \mathrm{SD}$ of three separate estimations. $I L 1 \beta$, Interleukin $1 \beta$; $T N F \alpha$, tumor necrosis factor alpha; $T G F \beta 1$, transforming growth factor $\beta 1$. $B$, Northern blot analysis of CNTF mRNA and GFAP mRNA after excitotoxic lesion with kainic acid. Fourteen day cocultures were
CNTF $m R N A$ and BDNF $m R N A$ are upregulated in neuron/ astrocyte coculture after kainiate addition

In order to determine whether CNTF mRNA levels could be regulated in neuron/astrocyte coculture, we applied purified factors which are known to regulate the levels of CNTF or IL6 in puritied astrocyte cultures (Fig. $3 A$ ).

We have shown previously that the $\alpha 2$ adrenergic agonist clonidine upregulates CNTF mRNA by twofold in rat hippocampal astrocyte cultures (Rudge et al., 1994a), as can $\gamma$ interferon (Carroll et al., 1994). In addition, Norris and Benveniste (1993) have shown that expression of the pleiotropic cytokine IL6, which shares receptor components with $\mathrm{CNTF}$ can be regulated by IL1 $\beta$ and TNF $\alpha$.

Of the different agents tested in this study, only kainic acid caused an increase in neurotrophic factor mRNA and protein. BDNF mRNA was elevated $6 \mathrm{hr}$ after kainate administration returning to baseline by $3 \mathrm{~d}$ (data not shown), similar to previous observations using purified hippocampal neurons (Zafra et al., 1992). In contrast, CNTF mRNA showed a more delayed elevation, increasing by 2.5 -fold, $24 \mathrm{hr}$ after kainate addition (Fig. $3 A$ ). Closer examination of the time course for CNTF mRNA showed a slight increase in CNTF mRNA at $6 \mathrm{hr}$, with maximal levels of five- to sixfold being reached after $48 \mathrm{hr}$ (Fig. $3 B$ ). Lcvels of GFAP mRNA increased by 1.5 -fold after $24 \mathrm{hr}$, but increased only slightly thereafter (Fig. $3 B$ ). The level of CNTF protein was also increased, showing a three- to fourfold increase (20 to $60-80 \mathrm{ng}$ CNTF/mg protein), $3 \mathrm{~d}$ after kainate lesion (Fig. $3 C$ ). When calculated on a per well basis, the increase in CNTF protein was 2.3-fold, $3 \mathrm{~d}$ after kainate lesion (data not shown). GFAP protein was unchanged after kainate whereas the $200 \mathrm{kDa}$ subunit of neurofilantent protein fell precipitously to undetectable levels, $24 \mathrm{hr}$ after kainate addition (Fig. $3 \mathrm{C}$ ).

\section{Neuronal loss correlates with the kainate induced upregulation of CNTF MRNA and protein}

As shown in Figure $3 A$, kainic acid was the only exogenous additive that increased the level of CNTF mRNA. However, examination of the cultures indicated that this was accompanied by neuronal cell loss suggesting that the increase in CNTF was due to a removal of the repressive influence of neurons on astrocyte expression of neurotrophic factors. This is in agreement with our findings in vivo where CNTF was found to be upregulated in reactive astrocytes after neuronal injury resulting, either from an aspiration lesion of the dorsal hippocampus and overlying cortex (Ip et al., 1993c) or an excitotoxic lesion of the adult rat hippocampus produced by systemic administration of kainic acid (Rudge et al., 1995). To further characterize the kainic acid lesion in vitro, we examined the time course of neuronal cell damage following the addition of $50 \mu \mathrm{M}$ kainic acid to the neuron/glial cocultures. Incorporation of propidium iodide into dead cells was used as a measure of cytotoxicity. Staining of

$\leftarrow$

extracted for RNA prior to the addition of kainic acid ( $50 \mu \mathrm{M})$ and then at $6 \mathrm{hr}, 24 \mathrm{hr}, 48 \mathrm{hr}$, and $72 \mathrm{hr}$ afterwards. Northern blots were probed for CNTFmRNA and GFAP mRNA and the resultant autoradiograms quantified on a Fuji Bioimager with PDQ software. $C$, Western blot analysis of CNTF, GFAP, and neurofilament after excitotoxic lesion with kainic acid. The regulation of CNTF, GFAP, and neurofilament proteins was measured prior to kainate addition and $24 \mathrm{hr}, 48 \mathrm{hr}$ and $72 \mathrm{hr}$ afterwards. Western blots were probed with the respective antibodies and quantified using a Perkin-EImer densitometer. 


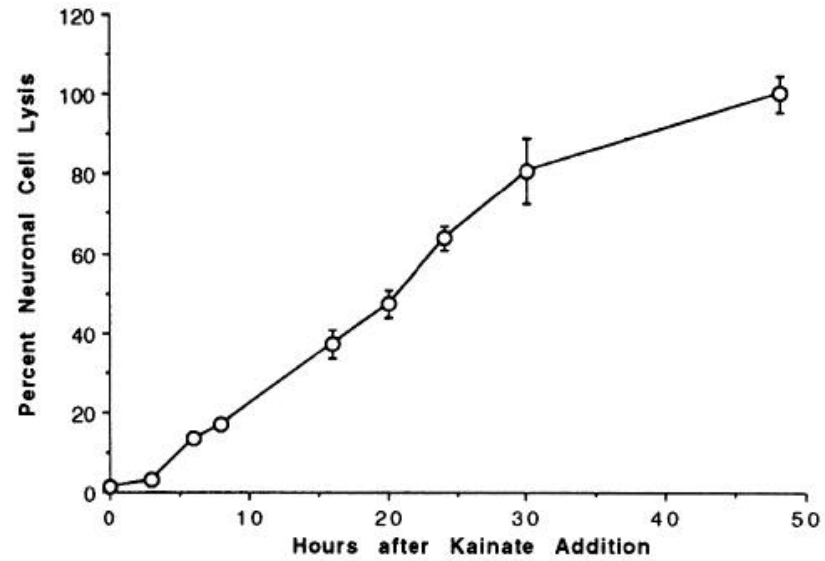

Figure 4. Development of the excitotoxic effect after administration of kainic acid to neuron/astrocyte coculture. Kainic acid $(50 \mu \mathrm{M})$ was added to neuron/astrocyte cocultures at $14 \mathrm{~d}$ of coculture and then acridine orange and propidium iodide were added for $30 \mathrm{~min}$ at $3,6,8$, $16,20,24,30$, and $48 \mathrm{hr}$ after kainate addition. The number of neurons incorporating propidium iodide over time was assessed on an inverted stage microscope with fluorescence optics and the percent neuronal cell lysis determined as a percentage of the number of neurons incorporating propidium iodide at $48 \mathrm{hr}$. (values are represented as the mean $\pm \mathrm{SD}$ from four separate cocultures).

live cells with acridine orange showed that cells with the characteristic morphology of neurons gradually died and incorporated propidium iodide with maximal cell loss occurring (Fig. 4; see also Fig. $3 C$ ). Over the same time course, astrocytes cultured alone or in coculture were not adversely affected by kainic acid, accounting for less than $1 \%$ of the cells incorporating propidium iodide at any of the time points examined (data not shown).

\section{$B D N F$ protein is upregulated in coculture after kainic acid lesion}

Although it has previously been shown that kainic acid administration to cultured rat hippocampal neurons causes a dramatic upregulation of BDNF mRNA (Zafra et al., 1992), it has not yet been shown how this affects BDNF protein levels. We have replicated the finding of induction of BDNF mRNA following kainate exposure and extended our study to also look at BDNF protein synthesis and TrkB signal transduction. In close agreement with the study of Zafra et al (1992) in purified neuronal cultures, we observed a maximal five- to sixfold increase in BDNF mRNA, $6 \mathrm{hr}$ after exposure to $25-50 \mu \mathrm{M}$ kainic acid. This similarity in dose response for the actions of kainate on purified neurons compared to coculture was also observed for neuronal loss and TrkB phosphorylation, suggesting that the protective effect of astrocytes on glutamate toxicity in culture (Rosenberg et al., 1992) is not applicable to kainate. The increase in BDNF mRNA in this culture system was followed by an increase in BDNF protein in extracts of the cocultures (Fig. 5A). The increase in BDNF protein reached maximal levels between 6 and $18 \mathrm{hr}$ after the addition of kainate and declined thereafter. However, at no time could we detect BDNF protein in the conditioned medium (within the limit of assay sensitivity, $8 \mathrm{pg} / \mathrm{ml}$ ) before or after kainate addition. Interestingly, when astrocytes cultured alone, before or after kainate addition were examined, no BDNF was detectable in either the cell extract or the medium (data not shown) suggesting that the $0.3 \mathrm{ng} / \mathrm{ml}$ of BDNF in the cell extract, $48 \mathrm{hr}$ after lesion, may be a lesion-induced expres-
A

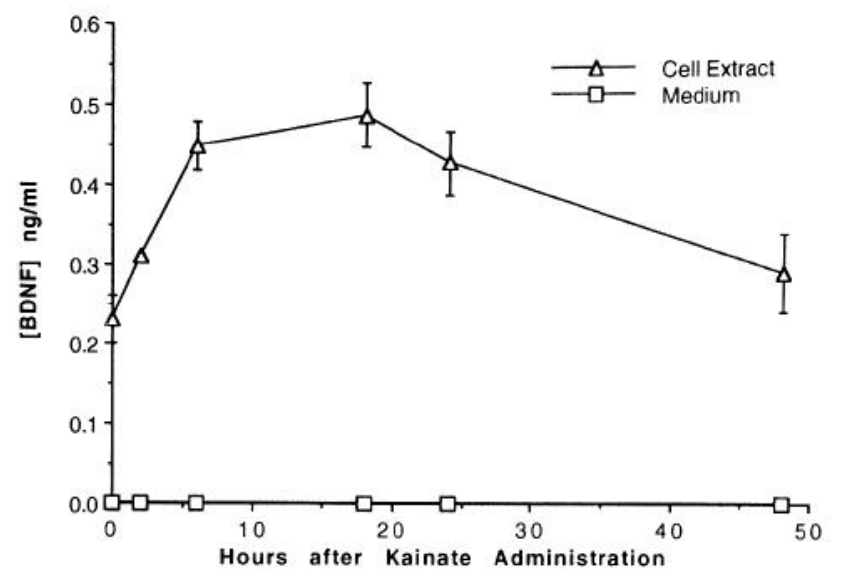

B $\quad k D \quad 0-0+2 h r \quad 6 h r \quad 18 h r \quad 1 d \quad 2 d$

C
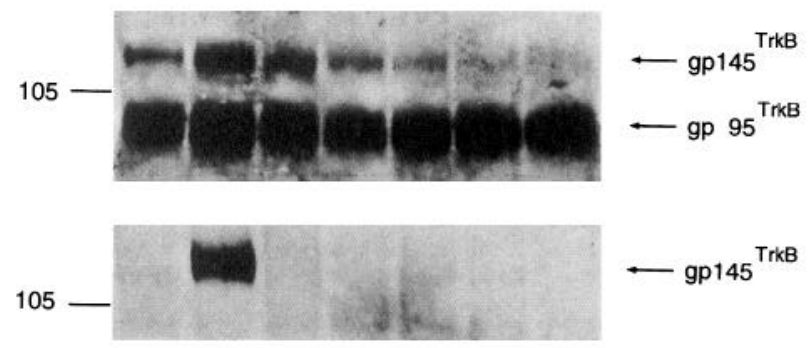

D

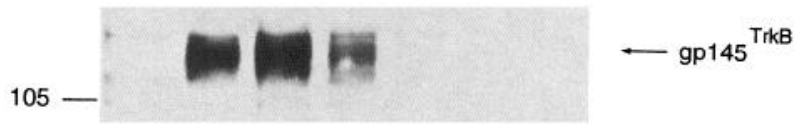

Figure 5. Regulation of BDNF protein and Trk B signal transduction after kainic acid lesion in neuron/astrocyte coculture. A, two-site ELISA. Conditioned media and cell extracts were taken prior to kainate (50 $\mu \mathrm{M})$ addition and then $2,6,18,24$, and $48 \mathrm{hr}$ afterwards. These samples were frozen at $-80^{\circ} \mathrm{C}$ prior to assay with a specific BDNF two-site ELISA. $B$, Trk B Western. Fourteen day cocultures were either extracted in lysis buffer $(0-)$ or treated with BDNF $(50 \mathrm{ng} / \mathrm{ml})(0+)$ for $5 \mathrm{~min}$ prior to extraction. The remaining cocultures were treated with kainic acid $(50 \mu \mathrm{M})$ and extracted in lysis buffer at $2 \mathrm{hr}, 6 \mathrm{hr}, 18 \mathrm{hr}, 24 \mathrm{hr}$, and $48 \mathrm{hr}$. Samples were precipitated with wheat germ agglutinin bound to agarose and bound material run on a Western blot. The blot was then probed for Trk B using a TrkB specific polyclonal antibody. $C$, TrkB phosphorylation before and after excitotoxic lesion. A similar set of cultures to that outlined in Figure $4 B$ was immunoprecipitated with a pan-Trk antibody and the resulting Western blot probed for phosphotyrosine. The only observable phosphorylation of TrkB was in lane 2 where exogenous BDNF $(50 \mathrm{ng} / \mathrm{ml})$ had been applied to the cocultures. $D$, TrkB phosphorylation on BDNF treated cocultures before and after excitotoxic lesion. A similar set of cultures to that outlined in Figure $4 B$ was treated with vehicle $(0-)$ or with $\operatorname{BDNF}(50 \mathrm{ng} / \mathrm{ml})$ for $5 \mathrm{~min}$ at $0+, 2,6,18,24$, and $48 \mathrm{hr}$ after kainic acid exposure and then immunoprecipitated with a pan-Trk antibody and the resulting Western blot probed for phosphotyrosine. The only observable phosphorylation of TrkB was in BDNF treated cultures prior to the addition of kainate.

sion of BDNF in astrocytes or a sequestration of neuronally released BDNF by astrocytes.

Increased levels of BDNF after excitotoxic lesion do not result in phosphorylation of TrkB

Figure $5 B$ shows that both the truncated and full length forms of TrkB are present in the present culture system, and that full 

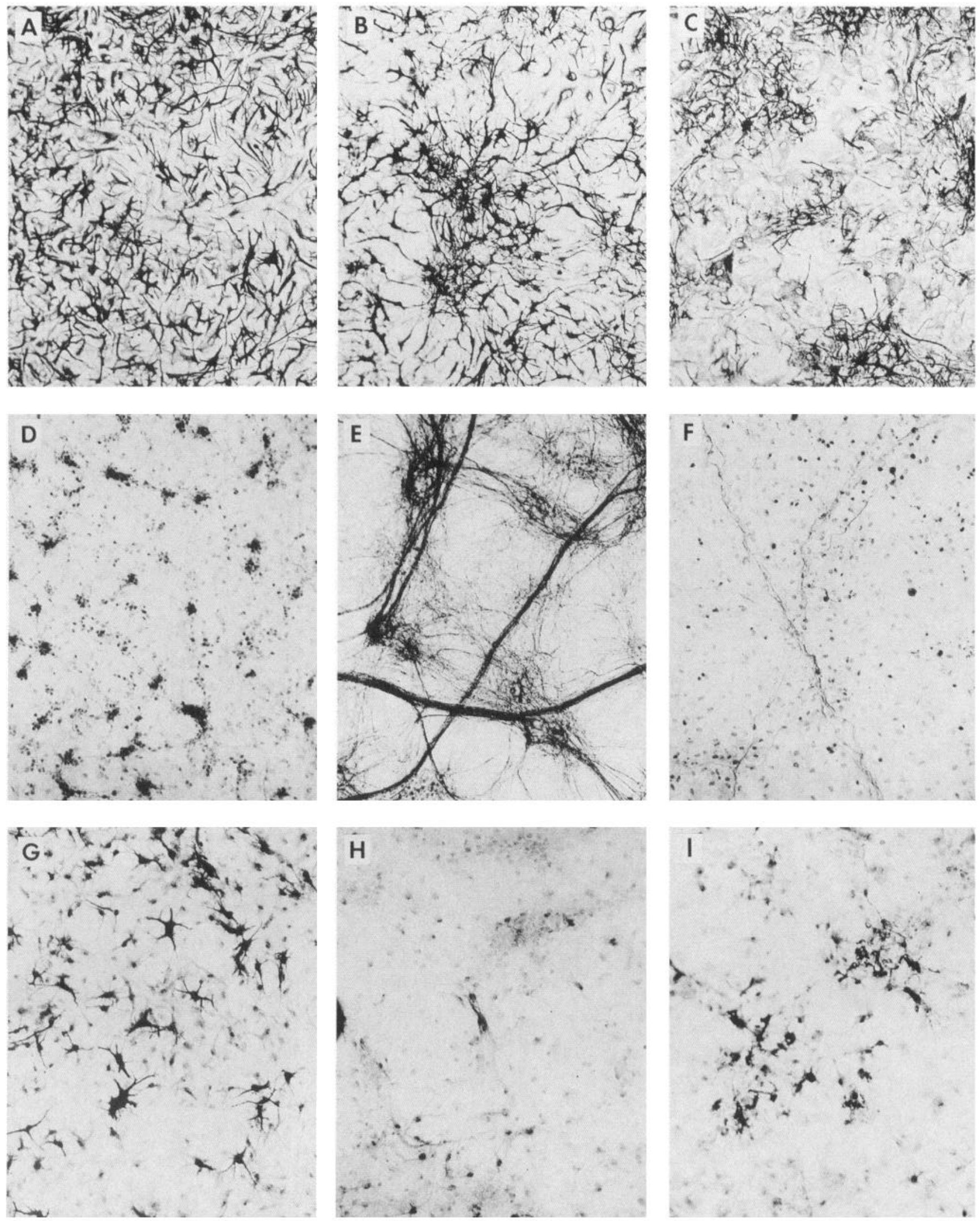

Figure 6. Morphological change and CNTF localization in astrocytes after kainate trreatment of hippocampal neuron/astrocyte cocultures. Astrocytes stained with an antibody to GFAP show a stellate morphology, $1 \mathrm{~d}$ after coculture with neurons $(A)$; this is more pronounced after $14 \mathrm{~d}$ in coculture $(B)$. Three days after the addition of kainate astrocytes have numerous vacuoles and a return to the flat epithelioid morphology indicative of astrocytes grown without neurons $(C)$. Neurons stained with a $200 \mathrm{kDa}$ neurofilament antibody are very sparse after $1 \mathrm{~d}$ in coculture $(D)$, but after $14 \mathrm{~d}$ there is a dense neuritic network covering the astrocyte monolayer $(E)$. There is a dramatic change $3 \mathrm{~d}$ after kainate addition with very few neuronal profiles observable $(F)$. CNTF staining is very evident in a population of astrocytes responding to the presence of neurons $1 \mathrm{~d}$ after 
length TrkB was lost over the same time course as the neurons died following exposure to kainate (see Fig. 4). Prior to the addition of kainate, full length TrkB (gp145 ${ }^{\text {TrkB }}$ ) was capable of being phosphorylated by the addition of exogenous BDNF (50 $\mathrm{ng} / \mathrm{ml}$ ) (Fig. $5 C, D, 0+\mathrm{BDNF}$ ). However, after the addition of kainate, gp $145^{\mathrm{TrkB}}$ was not phosphorylated by the endogenously upregulated BDNF at any time point examined (Fig. 5C) although the sensitivity of the phosphorylation assay would require greater than $5 \mathrm{ng} / \mathrm{ml}$ of BDNF in the medium to elicit a phosphorylation signal over background (data not shown). Moreover, following the excitotoxic insult, the addition of exogenous BDNF $(50 \mathrm{ng} / \mathrm{ml})$ was also unable to elicit phosphorylation of gp145 TrkB, at any time points after $6 \mathrm{hr}$ of treatment with kainic acid (Fig. 5D) even though detectable levels of gp $145^{\text {TrkB }}$ were present up to $24 \mathrm{hr}$ after kainate addition. Also, increasing the excitotoxic dose of kainic acid to $500 \mu \mathrm{M}$ dramatically reduced phosphorylation of TrkB by exogenous BDNF (data not shown).

\section{Changes in astrocyte morphology and CNTF expression after kainate lesion}

In order to assess how astrocytes respond to the presence and subsequent loss of neurons and to relate this to CNTF expression in astrocytes, we stained the cultures directly for GFAP, neurofilament protein and CNTF (Fig. 6). As described previously by Hatten and colleagues (Hatten, 1985; Gasser and Hatten, 1990), neurons induced stellation of astrocytes in coculture (Fig. 6A,B). However, $3 \mathrm{~d}$ after exposure to kainic acid with resulting neuronal loss, the majority of astrocytes reverted to a polygonal, epithelioid shape (Fig. 6C). Identifying the neurons by expression of the $200 \mathrm{kDa}$ neurofilament subunit showed that very little neurofilament had been produced by $1 \mathrm{~d}$ after seeding neurons onto the astrocytes (Fig. $6 D$ ). However, by $14 \mathrm{~d}$ there was a robust network of neurite processes and cables extending across the astrocyte surface (Fig. $6 E$ ). This was reflected in the 40 -fold increase in neurofilament protein shown in Figure $2 B$. By this criterion, excitotoxic lesion with kainic acid $(50 \mu \mathrm{M})$ was very effective in killing the neurons (Figs. $6 F, 5 B$ ). The staining pattern for CNTF was interesting in that coculturing with neurons caused the astrocytes to assume a stellate morphology and revealed very strong staining of a subpopulation of the astrocytes (Fig. 6G) (Stockli et al., 1991; Rudge et al., 1994a). Astrocytes ceased to express CNTF immunoreactivity after $14 \mathrm{~d}$ of coculture (Fig. $6 \mathrm{H}$ ). In agreement with the Western blotting data (Fig. $3 C$ ), CNTF levels rose dramatically after kainate lesioning. By immunocytochemical staining, this pattern was amorphous and did not fill the cytoplasm but surrounded phagocytic vacuoles which contained neuronal debris (Fig. 6I).

\section{Does the rise in CNTF after kainate lesion result in phosphorylation of the CNTF receptor?}

As we see such a dramatic rise in CNTF mRNA and protein after neuronal damage both in the present study and after lesion in vivo. (Ip et al., 1993), we addressed the question of whether the CNTF receptor $\beta$ components might be phosphorylated on tyrosine during the period of excitotoxic neuronal death in culture.

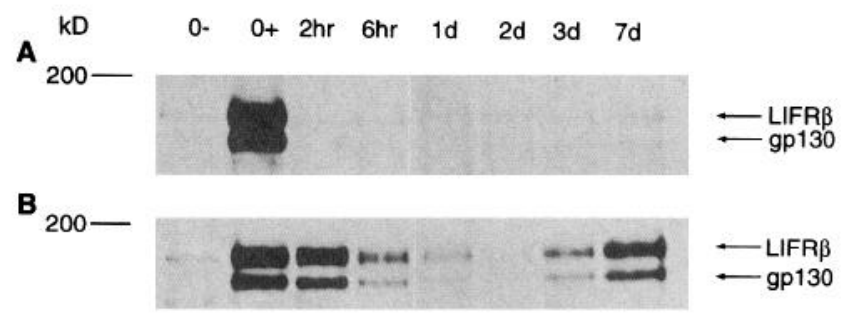

Figure 7. Tyrosine phosphorylation of LIFR $\beta$ and gp130 after kainic acid exposure. $A$, LIFR $\beta$ and gp130 phosphorylation after excitotoxic lesion. Fourteen day neuron/astrocyte cocultures were either extracted in lysis buffer $(0-)$ or treated with CNTF $(50 \mathrm{ng} / \mathrm{ml})(0+)$ for $15 \mathrm{~min}$ prior to extraction. The remaining cocultures were treated with kainic acid $(50 \mu \mathrm{M})$ and extracted in lysis buffer at $2,6,18,24$, or $48 \mathrm{hr}$. Samples were then immunoprecipitated with anti-LIFR $\beta$ and the bound material run on a Western blot which was then probed with an antiphosphotyrosine antibody. $B$, LIFR $\beta$ and gp130 phosphorylation in CNTF treated cocultures after excitotoxic lesion. To determine whether the CNTF receptor had the capacity to be phosphorylated after the addition of kainic acid, exogenous CNTF $(50 \mathrm{ng} / \mathrm{ml})$ was added to cultures for $15 \mathrm{~min}$ at time $0(0+), 2,6 \mathrm{~h}, 1 \mathrm{~d}, 2 \mathrm{~d}, 3 \mathrm{~d}$, and $7 \mathrm{~d}$ after the addition of kainate.

Figure 7, $A$ and $B$, shows that prior to kainate administration $(50 \mu \mathrm{M})$ to the cocultures, phosphorylation of the $\beta$ components of the CNTF receptor (LIFR $\beta$ and gp130) could be achieved by incubation of the cocultures with CNTF $(50 \mathrm{ng} / \mathrm{ml}$ ) (lane 2), resulting in higher levels of phosphorylation than observed in untreated controls (lane 1). Figure $7 A$ shows that after the addition of kainate and despite the ensuing increase in CNTF protein, there is no detectable phosphorylation of the $\beta$ components of the CNTF receptor throughout the period of neuronal death. However, unlike BDNF (Fig. 5D), administration of exogenous CNTF $(50 \mathrm{ng} / \mathrm{ml})$ resulted in receptor phosphorylation $2 \mathrm{hr}$ after kainate addition, declining to undetectable levels by $48 \mathrm{hr}$ but then returning to substantial levels of inducible phosphorylation $7 \mathrm{~d}$ after kainate addition (Fig. 7B). As shown in Figure 4, the majority of neurons are dead by $2 \mathrm{~d}$ after kainate administration, suggesting that the second phase of CNTF responsivity is due to upregulation of functional CNTF receptors on astrocytes. This result is similar to our findings in vivo where we show a switch of CNTF receptor expression from neurons to non-neuronal cells after an aspiration lesion of the adult rat hippocampus and overlying cortex (Rudge et al., 1994b).

\section{Discussion}

In recent years the classical view that neurons in the CNS rely solely on their targets for neurotrophic support (Thoenen, 1991; Lindsay et al., 1994) has been brought into question. This is due to a number of findings in which astrocytes have been shown to express neurotrophic factors (NTFs) during development (Lu et al., 1991) and after trauma (Sofroniew et al., 1990; Frautschy et al., 1991; Ip et al., 1993). The potential for astrocytes to express neurotrophic factors in vivo raises a number of interesting questions. (1) How does the neuron suppress neurotrophic factor production by astrocytes in the normal adult CNS, where astrocyte secretion of NTFs might be detrimental to the efficient functioning of the system? (2) How do neurons stimulate astrocytes 
to produce NTFs at times when they are required during development and after trauma? (3) Is there a time window after trauma but prior to their eventual loss in which neurons are still functionally responsive to neurotrophic factor administration? (4) Are NTFs as a whole broadly upregulated or are there signals which allow differential neurotrophic factor upregulation? (5) Are there contexts in which neurons are unable to respond to neurotrophic factors, despite the presence of their cognate receptors? (6) What are the consequences of simultaneous binding and/or activation of astrocytic and neuronal neurotrophic factor receptors? To begin to address these questions, we have utilized a defined neuronal/astrocyte culture system in which we can study the molecular mechanisms underlying neuronal control of astrocyte NTF expression and elucidate how this might be relevant under traumatic conditions.

A good example of a neurotrophic factor which may give some insight into the questions raised above is CNTF. This cytokine is present at very low levels in the adult CNS but is dramatically upregulated in astrocytes after traumatic injury (Ip et al., 1993). CNTF is also present at high levels in cultured astrocytes, so high, in fact, that astrocytes were used as the source for cloning rat CNTF (Stockli et al., 1989). Thus, CNTF was an ideal candidate to ask the question of whether the presence of neurons would be sufficient to suppress astrocyte expression of this neurotrphic factor.

In this study, we show that hippocampal neurons downregulate CNTF mRNA and CNTF protein expression in coculture as a dense neuritic network spreads out over the astrocytic monolayer. By $21 \mathrm{~d}$ in coculture, CNTF mRNA levels resemble those obseved in adult rat CNS. Attempts to upregulate CNTF in coculture by agents known to augment CNTF expression in astrocytes cultured alone (Rudge et al., 1994a) were unsuccessful, suggesting a stringent regulation of CNTF synthesis when neurons are in intimate contact with astrocytes. However, when neurons were damaged by administration of kainic acid, CNTF mRNA was increased in astrocytes in response to the dying neurons, reaching maximal levels $48 \mathrm{hr}$ after kainate administration. CNTF protein was also increased reaching maximal levels $3 \mathrm{~d}$ after lesion. To ascertain the functional consequences of this increase, we examined receptor phosphorylation. At no time during neuronal death and CNTF upregulation were the $\beta$ components of the CNTF receptor phosphorylated suggesting that during this period neither CNTF nor its family members which act through these receptors were released by dying neurons or astrocytes. However, when CNTF was exogenously applied, receptor phosphorylation could be induced at early stages after kainate addition. This was followed by a dormant period and then a return of inducible receptor phosphorylation on the remaining astrocytes.

\section{Astrocytes downregulate neurotrophic factor expression upon sustained contact with neurons in culture}

The close association between neurons and astrocytes during development involves a complex interchange of signals between these two cell types where macromolecules can be transferred from neuron to glia (Lasek et al., 1977) and astrocytes can develop a differentiated phenotype upon contact with neurons in culture (Gasser and Hatten, 1990). During development, diffusible signals in embryonic forebrain can control the identity of radial glial cells (Hunter and Hatten, 1995) which then act as supports for neuronal migration both in vitro (Gasser and Hatten, 1990) and in vivo (Rakic, 1971). The radial glial cells can then transform into astrocytes that are capable of providing energy substrates to more mature neurons under stress by controlling glycogenolysis (Sorg and Magistretti, 1991, 1992; Pellerin and Magistretti, 1994). In the same vein, the expression of neurotrophic factors by astrocytes in culture has led to the hypothesis that astrocytes in vivo may be capable of supplying their partner neurons with the appropriate factors necessary for their survival and maintenance (Varon et al., 1979; Manthorpe et al., 1986; Rudge 1993).

However, studies in vivo suggest that the neuron/glial relationship may be more dynamic where neurotrophic factors are involved. Under normal conditions in the adult CNS, the apparent lack of neurotrophic factor expression in astrocytes supports the view that neurotrophic factors are a means of communication between neurons signaling homeostasis in an efficiently functioning system. Neurotrophic factor release by astrocytes could be potentially detrimental to this system and upset the fine balance between neurons and their targets in the CNS. However, after injury or during disease, neuronal homeostasis is disrupted and the astrocyte begins to manufacture and secrete factors that support neurons under stress. Thus, reactive astrocytes in vivo and astrocytes in vitro deprived of their normal environment appear to react to the insult by synthesis of a number of supportive factors for the neuron, of which neurotrophic factors may only be a subset.

CNTF has been shown to possess a number of pleiotropic properties ranging from acute regulatory actions on synaptic function (Stoop and Poo, 1995), potent neurotrophic effects on injured dopaminergic substantia nigra neurons (Hagg and Varon, 1993) and cholinergic and noncholinergic septal neurons in vivo (Hagg et al., 1992), to actions on a number of non-neuronal cells (Schooltinck et al., 1992; Louis et al., 1993; Rudge et al., 1994b). Although exogenous CNTF is able to rescue both cholinergic and dopaminergic neurons from axotomy-induced degeneration, this factor alone is unable to sustain their neuronal phenotype (Hagg et al,, 1992). This is in contrast to members of the neurotrophin family such as NGF, which can sustain both the survival and neurotransmitter phenotype of specific neurons following axotomy (Hagg et al., 1992). Thus, CNTF and the neurotrophins may have complimentary roles in the CNS after trauma that result in the maintenance of a fully functioning neuron.

In our culture system, we have found that by coculturing neurons with astrocytes, we are able to downregulate both CNTF mRNA and protein to levels similar to those observed in the parenchyma in vivo (Stockli et al., 1991). The control of CNTF downregulation in coculture is also quite stringent, as exogenous factors which are capable of upregulating CNTF mRNA in astrocytes cultured alone are unsuccessful when administered to the coculture. This type of downregulation of neurotrophic factors in coculture has also been shown by Vige et al. where NGF was downregulated in cultures of cortical neurons with cortical astrocytes (Vige et al., 1992). This effect does not appear to be exclusive to hippocampal neurons as we have also observed down-regulation of CNTF mRNA in cocultures of rat hippocampal astrocytes with chick sympathetic neurons or PC12 phaeochromocytoma cells (data not shown).

However, upon lesioning the coculture with kainic acid, we can produce an upregulation of CNTF mRNA and protein similar to that observed after an aspirative lesion of the hippocampus and overlying cortex where CNTF levels are increased in reactive astrocytes (Ip et al., 1993c). 
Neuronal loss results in an upregulation of CNTF in astrocytes but this does not result in CNTF receptor activation

We have shown previously that an aspiration lesion to the dorsal hippocampus causes a dramatic upregulation in CNTF mRNA (Ip et al., 1993c) and CNTFR $\alpha$ mRNA (Rudge et al., 1994b) in the lesioned tissue surrounding the wound site. The expression of CNTF and its receptor in either the same cells or closely associated cells at the wound site raises the question as to whether CNTF may act in an autocrine or paracrine manner in the glial scar to initiate phenotypic responses in those cells which possess functional receptors. We have shown that cultured astrocytes and meningeal fibroblasts possess fully functional CNTF receptors (Rudge et al., 1994b) and that CNTF enhances survival in cultured rat hippocampal neurons (Ip et al., 1991).

In this study, we asked whether the rise in CNTF after lesion with kainic acid was reflected by an increase in CNTF receptor activation as measured by phosphorylation of the CNTF receptor complex. We found that during the time that CNTF is increased in astrocytes and that neurons are dying, no phosphorylation of LIFR $\beta$ or gp130 was detectable within the limits of sensitivity of our assay. The conclusion from this study is that CNTF increases within the astrocyte after neuronal injury but, due to the lack of a signal sequence (Stockli et al., 1989), is not released into the extracellular space. Thus, CNTF induced in astrocytes by injury can only be released if the astrocyte is sufficiently compromised to release its cytosolic contents. This may be one explanation for the enhanced survival of transplants in vivo when their insertion into a lesion cavity is delayed by 1 week (Nieto-Sampedro et al., 1983, 1984). Interestingly, the lesioned coculture shows two phases of response to exogenous addition of CNTF. In the first phase, prior to the addition of kainate, LIFR $\beta$ and gp130 are phosphorylated by the addition of $50 \mathrm{ng} /$ $\mathrm{ml}$ rat CNTF. After kainate addition, it is still possible to phosphorylate these receptors through exogenous CNTF addition but the response diminishes with the same time course as neuronal death, leading to a period at $48 \mathrm{hr}$ after kainate where the culture is refractory to CNTF. This period is then followed by an induction of responsivity to exogenous CNTF by the astrocytes in the culture. At this point, receptor phosphorylation reaches similar levels to that observed in astrocytes cultured alone. This switching from a neuronal expression of CNTF receptor to a non-neuronal expression also occurs in vivo after an aspiration lesion of the dorsal hippocampus and overlying cortex (Rudge et al., 1994b) and may reflect a shift for CNTF from the role of a neurotrophic factor to that of a pleiotropic cytokine after injury.

\section{Kainic acid lesion causes BDNF upregulation in coculture but} makes the neurons refractory to receptor activation

It has been established that seizure activity (Gall and Isackson, 1989; Isackson et al., 1991; Zafra et al., 1991) as well as a number of other types of insult (Zafra et al., 1990; Ballarin et al., 1991; Dugich-Djordjevic et al., 1992; Lindvall, 1992; Kokaia, 1993) are capable of causing dramatic increases in NGF mRNA and BDNF mRNA in adult rat hippocampus. The interpretation of these results was that although neurotrophin upregulation has been suggested as a protective mechanism to counteract cell death (Lindvall et al., 1994), extensive cell death still occurs in the CA1 and CA3 areas of the hippocampus despite neurotrophin upregulation. If we look at BDNF in particular, this result could be interpreted as (1) BDNF mRNA is increased but fails to translate to protein before the neuron is irreversibly compromised, (2) the neurotrophin protein is made but is sequestered by the high levels of truncated TrkB on the astrocyte (Frisen et al., 1993; Rudge et al., 1994b) and therefore never "sees" the functional TrkB on the injured neuron, or (3) the signal transduction mechanism for BDNF is somehow inactivated by the injury so that the increase in BDNF is ineffective. The coculture model that we have developed has allowed us to address the issues raised above.

We show that BDNF expression is upregulated after kainic acid lesion of hippocampal neurons in coculture, although the increase is observed only in the cell extract and never in the conditioned medium. However, regardless of any increase that occurs in BDNF protein, we also show that full length Trk B is not phosphorylated by endogenous BDNF (within the limits of sensitivity of our detection system) at any time after the addition of kainic acid. Thus, although injured neurons and their partner astrocytes respond to an excitotoxic insult by upregulating their levels of endogenous neurotrophic factors, this is clearly insufficient to protect the neurons from excitotoxic injury and death. This may be an abortive attempt at neuroprotection for neurons at the focal point of the injury but, in vivo, could possibly make a difference to neurons in the lesion penumbra. However, for the neurons that are directly affected, there is a narrow window, up to $6 \mathrm{hr}$ after the initiation of the kainic acid injury, in which both BDNF and CNTF receptors can be activated. Thus, it may be possible to pharmacologically administer BDNF and/or CNTF within this time frame, or alternatively induce the astrocytes to cxpress and/or release neurotrophic factors, to stabilize calcium levels within the neuron and ameliorate neuronal damage. We are in the process of addressing these questions in this system.

\section{Conclusions}

We have shown in this study that the intimate association of neurons with astrocytes can suppress astroglial expression of neurotrophic factors in vitro. This places the astrocyte under stringent controls such that addition of factors which are capable of upregulating neurotrophic factors in astrocytes cultured alone are unable to do so in coculture. However, excitotoxic lesion of the coculture with kainic acid results in a rapid upregulation of BDNF and a delayed upregulation of CNTF in astrocytes caused by removal of the neuronal repression. Although these neurotrophic factors are substantially upregulated, at no time do they initiate a functional response as measured by phosphorylation of their respective receptors. However, exogenously administered BDNF and CNTF can activate their receptors up to $6 \mathrm{hr}$ after excitotoxic injury providing a narrow window in which administration of these trophic factors may be able to ameliorate the excitotoxic insult.

\section{References}

Acheson A, Conover JC, Fandl JP, DeChiara TM, Russell M, Thadani A, Squinto SP, Yancopoulos GD, Lindsay RM (1995) A BDNF autocrine loop in adult sensory neurons prevents cell death. Nature 374: 450-453.

Altar CA, Armanini M, Dugich DM, Bennett GL, Williams R, Feinglass S, Anicetti V, Sinicropi D, Bakhit C (1992) Recovery of cholinergic phenotype in the injured rat neostriatum: roles for endogenous and exogenous nerve growth factor. J Neurochem 59:2167-2177.

Asada H, Ip NY, Pan L, Razack N, Parfitt NM, Plunkett RJ (1995) Time course of ciliary neurotrophic factor mRNA expression is coincident with the presence of protoplasmic astrocytes in traumatized rat striatum. J Neurosci Res 40:22-30. 
Ayer-LeLievre C, Olson L, Ebendal T, Seiger A, Persson H (1988) Expression of $\beta$-nerve growth factor gene in hippocampal neurons. Science 240:1339-1341.

Bandtlow CE, Meyer M, Lindholm D, Spranger M, Heumann R, Thoenen $H$ (1990) Regional and cellular codistribution of interleukin 1 beta and nerve growth factor mRNA in the adult rat brain: possible relationship to the regulation of nerve growth factor synthesis. J Cell Biol 111:1701-1711.

Banker GA (1980) Trophic interactions between astroglial cells and hippocampal neurons in culture. Science 209:809-810.

Berry M, Maxwell WL, Logan A, Mathewson A, McConnell P, Ashhurst DE, Thomas GH (1983) Deposition of scar tissue in the central nervous system. Acta Neurochir (Suppl) 32:31 53

Carman-Krzan M, Vige X, Wise BC (1991) Regulation by interleukin-1 of nerve growth factor secretion and nerve growth factor mRNA expression in rat primary astroglial cultures. J Neurochem 56 : 636-643.

Carroll P, Sendtner M, Meyer M, Thoenen H (1994) Rat ciliary neurotrophic factor (CNTF): gene structure and regulation of mRNA levels in glial cell cultures. Glia 9:176-187.

Condorelli DF, Dell'Albani P. Mudo G. Timmusk T, Belluardo N (1994) Expression of neurotrophins and their receptors in primary astroglial cultures: induction by cyclic AMP-elevating agents. J Neurochem 63:509-516.

Ernfors P, Ibanez CF, Ebendal T, Olson L, Persson H (1990) Localization of brain-derived neurotrophic factor mRNA to neurons in the brain by in silu hybridization. Exp Neurol 109:141-152.

Ferrara N, Ousley F, Gospodarowicz D (1988) Bovine brain astrocytes express basic fibroblast growth factor, a neurotropic and angiogenic mitogen. Brain Res 462:223-232.

Frautschy SA, Walicke PA, Baird A (1991) Localization of basic fibroblast growth factor and its mRNA after CNS injury. Brain Res 553:291-299.

Friedman WJ, Larkfors L, Ayer-LeLievre C, Ebendal T, Olson L, Persson $H$ (1990) Regulation of beta-nerve growth factor expression by inflammatory mediators in hippocampal cultures. J Neurosci Res 27 : $374-382$.

Friedman B, Scherer SS, Rudge JS, Ilelgren M, Morrisey D, McClain J, Wang DY, Wiegand SJ, Furth ME, Lindsay RM, Ip NY (1992) Regulation of ciliary neurotrophic factor expression in myelin-related Schwann cells in vivo. Neuron 9:295-305.

Frisen J, Verge VM, Fried K, Risling M, Persson H, Trotter J, Hokfelt T, Lindholm D (1993) Characterization of glial trkB receptors: differential response to injury in the central and peripheral nervous systems. Proc Natl Acad Sci USA 90:4971-4975.

Furukawa S, Furukawa Y, Satnyoshi E, Hayashi K (1986) Synthesis and secretion of nerve growth factor by mouse astroglial cells in culture. Biochem Biophys Res Commun 136:57-63.

Furukawa, S, Y Furukawa, E Satoyoshi and K Hayashi (1987) Regulation of nerve growth factor synthesis/secretion by catecholamine in cultured mouse astroglial cells. Biochem Biophys Res Commun 147: $1048-1054$.

Gall C, Murray K, Isackson PJ (1991) BDNF mRNA expression is increased in adult rat forebrain after limbic seizures: temporal patterns of induction distinct from NGF. Neuron 6:937-948.

Gasser UE, Hatten ME (1990) Neuron-glia interactions of rat hippocampal cells in vitro: glial-guided neuronal migration and neuronal regulation of glial differentiation. J Neurosci 10:249-258.

Hagg T, Varon S (1993) Ciliary neurotrophic factor prevents degeneration of adult rat substantia nigra dopaminergic neurons in vivo. Proc Natl Acad Sci USA 90:6315-6319.

Hagg T, Quon D, Higaki J, Varon S (1992) Ciliary Neurotrophic Factor prevents neuronal degeneration and promotes low affinity NGF receptor expression in the adult rat CNS. Neuron 8:145-158.

Hatten ME (1985) Neuronal regulation of astroglial morphology and proliferation in vitro. J Cell Biol 100:384-396.

Hunter KE, Hatten ME (1995) Radial glial cell transformation to astrocytes is bidirectional: regulation by a diffusible factor in embryonic forebrain. Proc Natl Acad Sci USA 92:2061-2065.

Ip NY, Li Y, van de Stadt I, Panayatatos N, Alderson RF, Lindsay RM (1991) Ciliary neurotrophic factor enhances neuronal survival in embryonic rat hippocampal cultures. J Neurosci 11:3124-3134.

Ip NY, Nye SH, Boulton TG, Davis S, Taga T, Li Y, Birren SJ, Yasukawa K, Kishimoto T, Anderson DJ, Yancopoulos GD (1992) CNTF and LIF act on neuronal cells via shared signaling pathways that involve the IL-6 signal transducing receptor component gp130. Cell 69:1121-1132

Ip NY, Li Y, Yancopoulos GD, Lindsay RM (1993a) Cultured Hippocampal Neurons Show Responses to BDNF, NT-3, and NT-4, but not NGF. J Neurosci 13:3394-3405.

Ip NY, McClain J, Barrezueta NX, Aldrich TH, Pan L, Li Y, Wiegand SJ, Friedman B, Davis S, Yancopoulos GD (1993b) The alpha component of the CNTF receptor is required for signaling and defines potential CNTF targets in the adult and during development. Neuron 10:89-102.

Ip NY, Wiegand SJ, Morse J, Rudge JS (1993c) Injury-induced regulation of ciliary neurotrophic factor mRNA in the adult rat brain. Eur J Neurosci 5:25-33.

Knusel B, Rabin SJ, Hefti F, Kaplan DR (1994) Regulated neurotrophin receptor responsiveness during neuronal migration and early differentiation. J Neurosci 14:1542 -1554

Lasek RJ, Gainer H, Barker JL (1977) Cell-to-cell transfer of glial proteins to the squid giant axon. The glia-neuron protein transfer hypothesis. J Cell Biol 74:501-523.

Lindholm D, Castren E, Hengerer B, Zafra F, Berninger B, Thoenen H (1992) Differential regulation of nerve growth factor (NGF) synthesis in neurons and astrocytes by glucocorticoid hormones. Eur J Neurosci 4:404 410

Lindsay RM (1979) Adult rat brain astrocytes support survival of both NGF-dependent and NGF-insensitive neurons. Nature 282:80-82.

Lindsay RM, Wiegand SJ, Altar CA, DiStefano PD (1994) Neurotrophic factors: from molecule to man. Trends Neurosci 17:182-190.

Lindvall O, Kokaia Z, Bengzon J, Elmer E, Kokaia M (1994) Neurotrophins and brain insults. Trends Neurosci 17:490-496.

Louis J-C, Magal E, Takayama S, Varon S (1993) CNTF protection of oligodendrocytes against natural and tumor necrosis factor-induced dcath. Science 259:689-692.

Lu B, Yokoyama M, Dreyfus CF, Black IB (1991) NGF gene expression in actively growing brain glia. J Neurosci 11:318-326.

Manthorpe M, Rudge JS, Varon S (1986) Astroglial cell contributions to neuronal survival and neuritic growth. In: Astrocytes: biochemistry, physiology and pharmacology of astrocytes (Fedoroff $S$, Vernadakis A, ed), pp 315-360. London: Academic.

Nieto-Sampedro M, Manthorpe M, Barbin G, Varon S, Cotman CW (1983) Injury-induced neuronotrophic activity in adult rat brain. Correlation with survival of delayed implants in a wound cavity. J Neurosci 3:2219-2229.

Nieto-Sampedro M, Whittemore SR, Needels DL, Larson J, Colman CW (1984) The survival of brain transplants is enhanced by extracts from injured brain. Proc Natl Acad Sci USA 81:6250-6254.

Norris JG, Benveniste EN (1993) Interleukin-6 production by astrocytes: induction by the neurotransmitter norepinephrine. J Neuroimmunol 45:137-146.

Pellerin L, Magistretti PJ (1994) Glutamate uptake into astrocytes stimulates aerobic glycolysis: a mechanism coupling neuronal activity to glucose utilization. Proc Natl Acad Sci 91:10625-10629.

Rakic P (1971) Neuron-glia relationship during granule cell migration in developing cerebellar cortex. A Golgi and electronmicroscopic study in Macacus rhesus. J Conp Neurol 141:283-312.

Rosenberg PA, Amin S, Leitner M (1992) Glutamate uptake disguises neurotoxic potency of glutamate agonists in cerebral cortex in dissociated cell culture. J Neurosci 12:56-61.

Rudge JS (1993) Astrocyte-derived neurotrophic factors. In: Astrocytes: pharmacology and function (Murphy SM, ed), pp 267-305. New York: Academic.

Rudge JS, Alderson RF, Pasnikowski EM, McClain J, Ip NY, Lindsay RM (1992) Expression of ciliary neurotrophic factor and the neurotrophins-nerve frowth factor, brain-derived neurotrophic factor and neurotrophin-3 in cultured rat hippocampal astrocytes. Eur J Neurosci 4:459-471.

Rudge JS, Morrissey D, Lindsay RM, Pasnikowski E (1994a) Regulation of ciliary neurotrophic factor in culture rat hippocampal astrocytes. Eur J Neurosci 6:218-229.

Rudge JS, Li Y, Pasnikowski EM, Mattsson K, Pan L, Yancopoulos GD, Wiegand S.I, Lindsay RM, Ip NY (1994b) Neurotrophic factor receptors and their signal transduction capabilities in rat astrocytes. Eur J Neurosci 6:693-705.

Rudge JS, Pasnikowski EM, Cai N, Wiegand SJ, Lindsay RM (1995) The $\beta$-adrenergic agonist clenbuterol attenuates neuronal loss and 
prevents CNTF up-regulation induced by systemic injection of kainic acid. IBRO Abstr A7.14:147.

Schooltinck H, Stoyan T, Roeb E, Heinrich PC, Rose-John S (1992) Ciliary neurotrophic factor induces acute-phase protein expression in hepatocytes. FEBS Lett 314:280-284.

Shao Y, McCarthy KD (1994) Plasticity of astrocytes. Glia 11:147155.

Sofroniew MV, Galletly NP, Isacson O, Svendsen CN (1990) Survival of adult basal forebrain cholinergic neurons after loss of target neurons. Science 247:338-342.

Sorg O, Magistretti PJ (1991) Characterization of the glycogenolysis elicited by vasoactive intestinal peptide, noradrenaline and adenosine in primary cultures of mouse cerebral cortical astrocytes. Brain Res 563:227-233.

Sorg O, Magistretti PJ (1992) Vasoactive intestinal peptide and noradrenaline exert long-term control on glycogen levels in astrocytes: blockade by protein synthesis inhibition. J Neurosci 12:4923-4931.

Stockli KA, Lottspeich F, Sendtner M, Masiakowski P, Carroll P, Gotz R, Lindholm D, Thoenen H (1989) Molecular cloning, expression and regional distribution of rat ciliary neurotrophic factor. Nature 342:920-923.

Stockli KA, Lillien LE, Naher-Noe M, Breitfeld G, Hughes RA, Raff MC, Thoenen H, Sendtner M (1991) Regional distribution, developmental changes, and cellular localization of CNTF-mRNA and protein in rat brain. J Cell Biol 115:447-459.

Stoop R, Poo M-M (1995) Potentiation of transmitter release by ciliary neurotrophic factor requires somatic signalling. Science 267:695699.

Thoenen H (1991) The changing scene of neurotrophic factors. Trends Neurosci 14:165-170.

Varon S, Somjen G (1979) Neuron-glia interactions. Neurosci Res Prog Bull 17:1-239.

Vige X, Tang B, Wise BC (1992) Cortical neurons inhibit basal and interleukin 1 stimulated astroglial cell secretion of nerve growth factor. Neurosci Lett 591:345-350.

Whittemore SR, Friedman PL, Larhammar D, Persson H, GonzalezCarvajal M, Holets VR (1988) Rat beta-nerve growth factor sequence and site of synthesis in the adult hippocampus. J Neurosci Res 20:403-410.

Yamakuni T, Ozawa F, Hishinuma F, Kuwano R, Takahashi Y, Amano T (1987) Expression of b-nerve growth factor mRNA in rat glioma cels and astrocytes from rat brain. FEBS Lett 223:117-121.

Yoshida K, Gage FH (1992) Cooperative regulation of nerve growth factor synthesis and secretion in fibroblasts and astrocytes by fibroblast growth factor and other cytokines. Brain Res 569:14-25.

Zafra F, Hengerer B, Leibrock J, Thoenen H, Lindholm D (1990) Activity dependent regulation of BDNF and NGF mRNAs in the rat hippocampus is mediated by non-NMDA glutamate receptors. EMBO J 9:3545-3550.

Zafra F, Lindholm D, Castren E, Hartikka J, Thoenen (1992) Regulation of brain-derived neurotrophic factor and nerve growth factor mRNA in primary cultures of hippocampal neurons and astrocytes. J Neurosci 12:4793-4799. 